\title{
PELATIHAN PEMBELAJARAN IPA BERBASIS KETERAMPILAN PROSES DI PDM BANTUL YOGYAKARTA
}

\author{
Oleh: \\ Dian Artha K, Fajar Fitri, Nanang Suwondo \\ Universitas Ahmad Dahlan, Jl. Prof. Dr. Supomo, S.H. Warungboto, Yogyakarta \\ E-mail: dian_uad@yahoo.com
}

\section{Ringkasan}

Keterampilan proses dalam pembelajaran harus ditumbuhkan dalam diri siswa sesuai dengan taraf perkembangan pemikirannya. Keterampilan ini akan menjadi roda penggerak penemuan dan pengembangan fakta dan konsep sikap, wawasan, dan nilai siswa. Namun, pada saat ini masih banyak guru IPA SMP Muhammadiyah terutama di lingkungan kabupaten Bantul belum melaksanakan pembelajaran keterampilan proses dan belum mengembangankan instrumen evaluasinya. Dengan demikian perlu dilakukan pelatihan pengembangan instrument evaluasi pembelajaran IPA berbasis keterampilan proses. Pelatihan berhasil dilaksanakan pada tanggal 1718 Mei 2017 di gedung PDM Bantul dengan jumlah peserta 12 guru IPA SMP Muhammadiyah. Pelatihan dilaksanakan selama dua hari dengan materi: Pembelajaran IPA berbasis Ketrempilan Proses Menggunakan Arduino sebagai Media Pembelajaran dan Pengembangan Instrumen Evaluasi Pembelajaran IPA Berbasis Keterampilan Proses. Berdasarkan pelatihan ini, maka guru-guru memahami bagaimana pembelajaran keterampilan proses dalam IPA dan memahami bagaimana mengembangkan instrument evaluasinya. Berdasarkan hal ini maka diperoleh kesimpulan bahwa berdasarakan pelatihan yang telah diselenggarakan, maka sebagian besar guru-guru IPA SMP Muhammadiyah di kabupaten Bantul memahami tentang instrumen evaluasi pembelajaran berbasis keterampilan proses dan mampu mengembangkannya.

Kata Kunci: Instrumen Evaluasi, Pembelajaran Ipa, Keterampilan Proses.

\begin{abstract}
Process skills in learning should be grown in students according to the level of development of their thinking. This skill will be the driving wheel of discovery and development of facts and concepts of attitudes, insights, and grades. However, at this time there are still many science teachers of SMP Muhammadiyah especially in Bantul regency has not implemented process learning skill and has not developed its evaluation instrument. Thus, it is necessary to conduct training on the development of evaluation instrument of science-based learning process skill. The training was successfully held on 17-18 May 2017 at Bantul PDM building with the number of participants of 12 science teachers of SMP Muhammadiyah. The training was conducted for two days with the materials: Scientific Learning based on Arranginal Process Using Arduino as Learning Media and Development Instrument for Learning Evaluation of Science-Based Scientific Skills. Based on this training, teachers understand how to learn process skills in science and understand how to develop their evaluation instruments. Based on this, it is concluded that based on the training that has been held, the majority of science teachers of SMP Muhammadiyah in Bantul district understand about the evaluation instrument of skills-based learning process and able to develop it.
\end{abstract}

Keywords: Evaluation Instrument, Ipa Learning, Process Skill.

\section{A. PENDAHULUAN}

Sesuai dengan karakteristik IPA yang berupa penguasaan pengetahuan dan juga proses penemuan, maka terdapat dua hal yangberkaitan dengan IPA yakni sebagai produk (pengetahuan yang berupa fakta, konsep, prinsip, hukum, dan teori) dan IPA sebagai proses (kerja ilmiah). Oleh karena itu, penilaian hasil belajar IPA harus memperhatikan 
karakteristik IPA sebagai proses dan produk. Selain itu, pembelajaran IPA juga menekankan pada pemberian pengalamanbelajar secara langsung melalui penggunaan dan pengembangan keterampilan proses. Keterampilan proses dalam pembelajaran harus ditumbuhkan dalam diri siswa sesuai dengan taraf perkembangan pemikirannya. Keterampilan ini akan menjadi roda penggerak penemuan dan pengembangan fakta dan konsep sikap, wawasan, dan nilai siswa.

Pada saat ini, masih banyak guru yang belum melaksanakan proses pembelajaran dengan mengembangkan keterampilan proses. Keterampilan proses baru dikenal secara harfiah, karena ada pendapat bahwa dengan menguasai konsep-konsep IPA, pembelajaran sudah selesai tanpa perlu mengembangkan keterampilan proses dalam pembelajaran IPA. Penilaian berbasis keterampilan proses ini menggunakan berbagai bentuk dan model penilaian yang dilakukan secara sistematis dan sistemik, menyeluruh, dan berkelanjutan. Diharapkan penilaian ini mampu memperoleh data dan informasi secara utuh serta gambaran prestasi dan kemajuan belajar siswa dan untuk memberikan penghargaan dan keadilan terhadap semua kegiatan siswa. Berdasarkan latar belakang masalah tersebut, maka pengabdi berupaya akan melakukan sebuah pelatihan bagi guru-guru IPA se kabupaten Bantul di PDM Bantul dalam mengembangkan instrumen penilaian berbasis keterampilan proses.

Melalui kegiatan pengabdian ini diharapkan memperoleh hasil berupa pelatihan pengembangan instrumen penilaian IPA berbasis keterampilan proses, memberikan pengetahuan dan pengalaman bagi guru IPA SMP dalam mengembangankan instrumen penilaian berbasis keterampilan proses, dan memberikan pendampingan pengembangan instrumen penilaian keterampilan proses bagi guru.

\section{B. SASARAN \& METODE PELAKSANAAN}

Sasaran kegiatan yakni guru-guru IPA SMP di kabupaten Bantul sebanyak 21 guru yang tersebar pada 21 sekolah Muhammadiyah. Kegiatan pengabdian direncanakan berlangsung pada bulan April 2017 melalui perencanaan, pada bulan Mei 2017 pada pelaksanaan, dan pada bulan Juni 2017 pada evaluasi dan pembuatan laporan. Pelatihan dan pendampingan pelatihan semuanya membutuhkan waktu sekitar 16 jam.

Kegiatan pengabdian ini dilakukan melalui tiga tahapan. Tahapan perencanaan, tahap pelaksanaan, dan tahap evaluasi. Tahap perencanaan dilakukan melalui koordinasi dengan guru IPA dan kepala sekolah di SMP Muhammadiyah Bantul. Hasil koordinasi kemudian dijadikan sebagai bahan masukan di dalam pelaksanaan pelatihan. Selanjutnya melakukan hubungan kerjasama atau kesepakatan pelatihan dengan pihak-pihak terkait, yakni pada Dikdasmen PDM Bantul, sebagai pihak yang menyediakan tempat pelatihan.

Tahap pelaksanaan merupakan tahap pelatihan pengembangan instrumen dan pendampingan guru di dalam mengembangkan instrumen penilaian. Tahap terakhir adalah evaluasi yakni dengan cara membagikan angket kepada guru tentang pendapat mereka terhadap pelaksanaan pelatihan. 
Diterbitkan oleh Lembaga Pengabdian kepada Masyarakat

Universitas Ahmad Dahlan Yogyakarta

\section{HASIL DAN PEMBAHASAN}

Hasil pengabdian yakni peserta pelatihan yang datang pada pelatihan sebanyak 12 guru IPA SMP Muhammadiyah se kabupaten Bantul. Mahasiswa dilibatkan dalam pelatihan ini yakni sebanyak 4 orang mahasiswa yang bertugas mengantar undangan, 4 orang mahasiswa sebagai asisten pelatihan, dan sebanyak 2 orang mahasiswa yang bertugas menerima tamu dan seksi konsumsi.

Pelatihan dilaksanakan selama 2 hari di gedung PDM Bantul pada tanggal 17-18 Mei 2017. Hari pertama diisi dengan materi Pembelajaran Berbasis Keterampilan Proses dengan menggunakan media pembelajaran Arduino oleh Bapak Nanang Suwondo, M.Pd.Si.

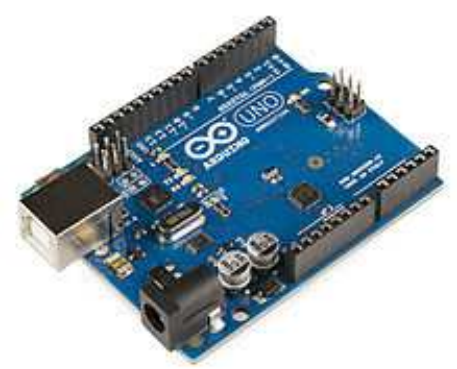

Gambar 1. Media Arduino

Sumber: https://upload.wikimedia.org/wikipedia/commons/3/38/Arduino_Uno_-_R3.jpg

Guru diberikan penjelasan bagaimana Arduino bisa dijadikan sebagai alternatif media pembelajaran pada saat menyampaikan materi Elektronika di SMP. Sepanjang pelatihan, guru nampak antusias, mereka dibuat berkelompok untuk mencoba mempraktekkan menggunakan Arduino. Saat parktek, pembicara pelatihan dibantu oleh dua orang mahasiswa sebagai asisten untuk mendampingi guru.

Pada hari kedua, guru diberikan pelatihan mengenai pembuatan instrumen penilaian IPA berbasis keterampilan proses. Pembicara pelatihan hari kedua adalah Dian Artha Kusumaningtyas, M.Pd.Si. Pada saat pelatihan, guru diberikan penjelasan mengenai instrumen evaluasi yang terbaru. Kemudian guru diberikan gambaran tentang contoh instrumen evaluasi yang diharapkan. Pada saat pelatihan ini pemateri juga memaparkan tentang beberapa kriteria penilaian seperti yang digambarkan pada Tabel 1. di bawah ini:

Tabel. 4.1 Ranah Kemampuan Siswa

\begin{tabular}{|l|l|l|}
\hline R. Kognitif (C) & R. Afektif (A) & R. Psikomotor (P) \\
\hline $\mathrm{C}_{6}$ Penilaian & $\mathrm{A}_{5}$ Menjadi PolaHidup & $\mathrm{P}_{5}$ Gerak Kompleks \\
\hline $\mathrm{C}_{5}$ Sintesis & $\mathrm{A}_{4}$ Mengatur Diri & $\mathrm{P}_{4}$ Gerak Mekanik \\
\hline $\mathrm{C}_{4}$ Analisis & $\mathrm{A}_{3}$ Menghargai & $\mathrm{P}_{3}$ Menirukan \\
\hline $\mathrm{C}_{3}$ Penerapan & $\mathrm{A}_{2}$ Menanggapi & $\mathrm{P}_{2}$ Siap Bertindak \\
\hline $\mathrm{C}_{2}$ Pemahaman & $\mathrm{A}_{1}$ Menerima & $\mathrm{P}_{1}$ Persepsi \\
\hline $\mathrm{C}_{1}$ Ingatan & & \\
\hline
\end{tabular}


Saat berlangsung pelatihan, guru nampak antusias dan aktif. Keaktifan tersebut dapat dilihat pada Gambar 3. yang merupakan kondisi berlangsungnya pelatihan. Sedangkan Gambar 4. merupakan gambar keterlibatan mahasiswa dalam pelatihan.

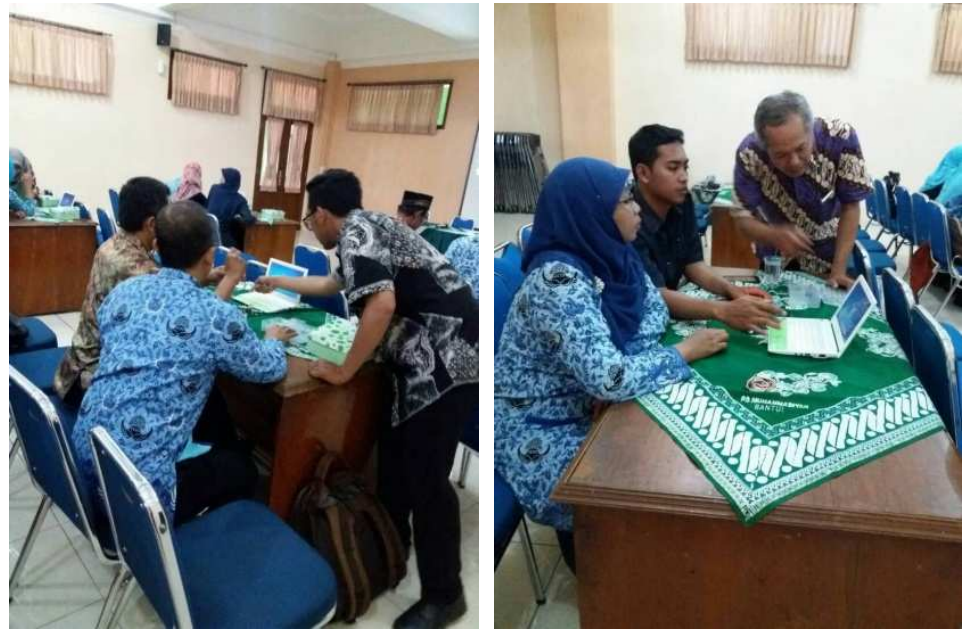

Gambar 2. Keaktifan Peserta pada Saat Pelatihan

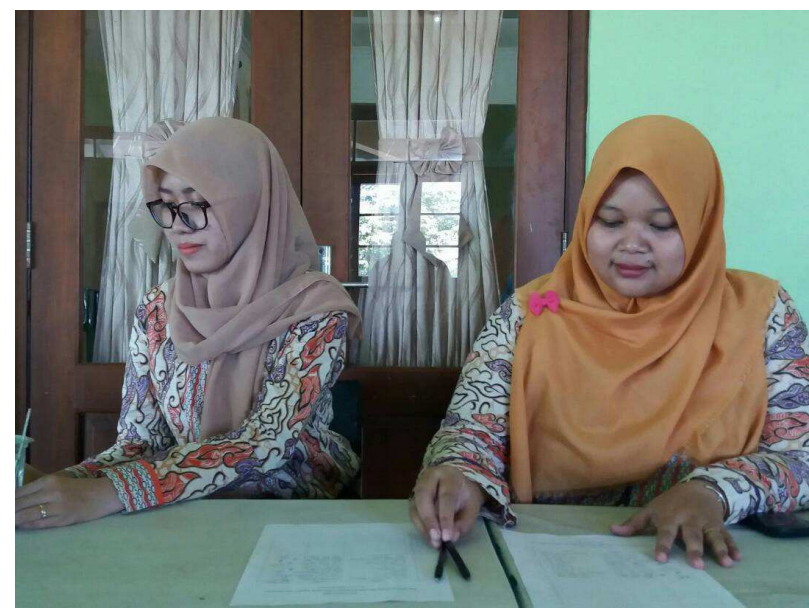

Gambar 3. Keterlibatan Mahasiswa dalam Pelatihan

Selama pelatihan guru nampak antusias mengikutinya. Banyak pertanyaan dan diskusi yang disampaikan oleh guru terhadap materi yang disampaikan. Berdasarkan pelatihan tersebut didapatkan beberapa evaluasi diantaranya:

1. Perlu koordinasi intensif antara pengabdi dengan PDM maupun guru IPA terkait agenda dan kegiatan yang penting.

2. Pelatihan oleh dosen untuk guru-guru IPA harus sering dilakukan untuk meningkatkan wawasan dan kemampuan guru.

3. Perlu adanya kerjasama baik dalam pelatihan maupun penelitian antara dosen dan guru. 
Diterbitkan oleh Lembaga Pengabdian kepada Masyarakat

Universitas Ahmad Dahlan Yogyakarta

\section{SIMPULAN}

Berdasarakan pelatihan yang telah diselenggarakan, maka sebagian besar guruguru IPA SMP Muhammadiyah di kabupaten Bantul memahami tentang instrumen evaluasi pembelajaran berbasis keterampilan proses dan mampu mengembangkannya.

\section{DAFTAR PUSTAKA}

Depdiknas, 2006. Model Pembelajaran Terpadu IPA SMP/MTs. SMP LB. Pusat Kurikulum Balitbang Diknas.

Dimyati dan Mudjiono. (2009). Belajar dan Pembelajaran. Jakarta: Rineka Cipta

Firman, H. (2000). Penilaian Hasil Belajar dalam Pengajaran Kimia. Bandung: Jurusan Pendidikan Kimia FPMIPA UPI

MilyaSari.2012.HakekatPendidikansains/IPA.

https://kajianipa.wordpress.com/2012/03/28/hakekat-pendidikan-sians/. Diakses tanggal 23 Februari 2017.

Permendiknas No 22 tahun 2006 tentang Standar Isi, untuk IPA SD/MI dan SMP/MTs.

Rustaman, N.Y., dkk. (2003). Strategi Belajar Mengajar Biologi. Bandung: Jurusan Pendidikan Biologi FPMIPA UPI 
